\title{
Okul Yöneticilerinin Okul Gelişim Modeli ile İlgili Görüşleri1
}

\author{
DOI: 10.26466/opus.667359
}

*

\author{
Fatih Bozbayındır* - Sedat Alev ** \\ * Dr. Öğretim Üyesi, Gaziantep Üniversitesi, Nizip Eğitim Fakültesi, Gaziantep/Türkiye \\ E-Posta: fatihbozbayindir@gmail.com ORCID: 0000-0001-5393-0955 \\ ** Dr, MEB, Şahinbey Belediyesi Bilim ve Sanat Merkezi, Gaziantep/Türkiye \\ E-Posta: sedat2783@gmail.com \\ ORCID: 0000-0003-4506-4756
}

\section{Öz}

Bu araştırmada, okul yöneticilerinin okul gelişim modeline ilişkin görüşlerinin belirlenmesi amaçlanmıştır. Nitel araştırma deseni ile yürütülen araştırmada, durum çalışması deseni kullanılmıştır. Çaıışma grubu 2018-2019 eğitim-öğretim yılında Gaziantep'teki ilkokullarda görev yapan 21 okul yöneticisinden oluşmaktadır. Yar yapılandırılmış görüşme formu ile toplanan verilerin analizi MAXQDA 2018 nitel veri analizi programı ile yapılmıştır. Verilerin analizinde, betimsel analiz ve içerik analizi kullanılmıştır. Araştırma sonucunda yöneticiler okul gelişiminin planlı ve sistemli bir şekilde okulu geliştirmek ve akademik başarıyı arttırmak için yapıldığını, hedeflerin belirlenmesinde uygulanabilirliğin göz önünde bulundurulması gerektiğini ifade etmişlerdir. Hedefe ulaşabilmek için planlamanın önemli ve gerekli olduğu, planlama sürecinde okulla ilgili tüm paydaşların rol alması gerektiği belirtilmiştir. Okul gelişiminin să̆lanması için okulların fiziki yapılarının iyileştirilmesi ve yeterli kaynağın verilmesinin önemli olduğu, değerlendirme aşamasında ise hedeflerin gerçekleşme düzeyinin ve okulun akademik başarısının ölçüt olarak alınması gerektiği vurgulanmıştır. Eğitim-öğretim faaliyetlerinin etkili bir şekilde gerçekleştirilmesi için tüm paydaşların sürece aktif katılımının sağlanması, olumlu ve güven odakl bir okul kültürünün oluşturulması önemli görülmektedir. Okullarının gelişiminin sağlanması için, yeterli kaynağın sağlanması, çevresel şartların dikkate alınması ve fiziki şartların uygun hale getirilmesi gerekmektedir. Öğretmenlerin yeterliliklerini geliştirmeye yönelik çalışmalar yapılmasının, onların yenilik ve değişimlerde daha aktif rol alarak okul gelişimini desteklemelerini sağlayacağı düşünülmektedir.

Anahtar Kelimeler: Okul gelişim modeli, yönetici, okul

\footnotetext{
${ }^{1}$ Bu çalışma, 14. Uluslararası Eğitim Yönetimi Kongresi'nde sözlü bildiri olarak sunulmuştur
} 


\title{
School Administrators' Perceptions of School Development Model
}

\begin{abstract}
In this study, it was aimed to determine school administrators' perceptions of the school development model. In the study conducted with the qualitative research design, the case study design was adopted. The study group consists of 21 school administrators, who serve in primary schools in Gaziantep during the 2018-2018 education period. The analysis of the data, which was collected by the semi-structured interview form, was conducted in the MAXQDA2018 qualitative data analysis software. In the data analysis, descriptive analysis and content analysis techniques were employed. As a result of the study, the administrators stated that school development was conducted to develop the school and improve academic achievement in a planned and systematic way and expressed that practicality should be considered while setting goals. It was also stated that planning is vital and necessary to achieve goals and every stakeholder in schools should have parts in the planning process. Additionally, it was emphasized that the physical conditions of schools should be improved and sufficient resources should be provided to enable schools' development. The administrators also noted that the achievement level of the goals and academic achievement of schools should be considered as benchmarks in the evaluation phase. To conduct educational effectively, it is viewed vitally important to ensure that every stakeholder actively participates in the process and to form a positive and confidence-focused school culture. To ensure schools' development, sufficient resources should be provided while taking environmental conditions into account and rending physical conditions accommodating. It is believed that conducting studies on developing teachers' competences will enable them to support schools' development by encouraging them to play more active parts in innovation and transformation.
\end{abstract}

Keywords: Keywords School development model, administrator, school 


\section{Giriş}

Teknolojik gelişmelerin hızlı bir şekilde yaşandı̆̆ı, bilimsel bilginin değerinin giderek arttı̆̆; değişim ve gelişim olgusunun hayatın her yönüne etki ettiği günümüzde, yaşanan değişimin eğitim alanına da etki etmesi kaçınılmaz hale gelmiştir (Altun ve Bebek, 2016). Eğitim-öğretim faaliyetlerinin gerçekleştirildiği okullarda, yönetici ve öğretmenlerin değişime karşı gösterdikleri tepkilerin eğitim öğretim faaliyetlerinin verimlilik ve etkililiği üzerinde önemli bir rolü bulunmaktadır (Bozbayındır ve Alev, 2018). Diğer bir ifadeyle, okulların yaşanan değişim ve yeniliklere adapte olabilmeleri, planlı bir şekilde okul gelişimini sağlamaya yönelik faaliyetlerde bulunmaları önemli görülmektedir. Okul gelişimin başarılı olması için değişimin doğru bir şekilde yönetilmesi gerekmektedir (Clarke, 2000; Haris, 2002; Heck ve Hallinger, 2010; Opdenakker ve Damme, 2007; Penlington, Kington ve Day, 2008). Özellikle, okulların daha nitelikli eğitim ve öğretim verebilmelerinde, istek ve ihtiyaçlar doğrultusunda yapılan okul gelişim planlama süreci oldukça önemlidir (Gökyer, 2011). Okul geliştirme, genelde eğitimin özelde ise okulun amaçlarının daha etkili bir biçimde gerçekleştirilmesini sağlayarak okulu geliştirmeyi ve öğrenci başarısını arttırmayı hedefleyen bir yaklaşım olarak değerlendirilebilir. Bu yönüyle okul geliştirme temelde öğrenme-öğretme süreçlerine odaklanma ve bu süreci destekleyen koşullar içerisinde öğrenci başarısını artırmayla ilgili olduğu için, planl, sürekli ve sistemli olması gerekmektedir (Reynolds vd., 2006; Şahin, 2006; Balc1, 2011). Benzer doğrultuda, Hopkins (2004), okul geliştirme modelinin, bir okulla ilgili sorunların bir bütün olarak ele alındığı ve bu sorunları süreç odaklı bir şekilde durumsal şartları göz önünde bulundurarak çözmeyi amaçlayan bir süreç olduğunu belirtmiştir.

Altun ve Bebek (2016) tarafından yürütülen bir araştırma sonucunda, okulun gelişiminin, okulun fiziksel imkânlarının gelişmişliği, öğretmenlerin meslek sevgisi ve öğrencilerin akademik başarısı ile ilgili olduğu ortaya çıkmıştır. Diğer bir ifadeyle okul gelişiminin çok yönlü bir süreç olduğunu ve bu süreçte okulun fiziki şartlarının yanı sıra öğretmen yeterliliğinin uygun olmasının okul gelişiminde önemli rol oynayacağını söylemek mümkündür. Bu ifadeyi destekler nitelikte yapılan çeşitli araştırmalarda da (Poyraz ve Dere, 2003; Karaküçük, 2008) okulların fiziksel açıdan yeterli olmasının öğrencilerin ve dolayısıyla okulun başarısı için önemli bir faktör olduğu belirtilmiştir. 
Buna ek olarak öğretmenlerin mesleklerini sevmeleri okulun gelişimini olumlu yönde etkilemektedir (Ada vd., 2013; Altun ve Bebek, 2016). Okulun alt yapı imkânlarının yeterliliği, öğretmenlerin gelişimlerinin desteklenmesi ve öğrencilerin araştırmaya sevk edilmesi okulun gelişimi için önemlidir (Turan, 2002; Balkar ve Özgan, 2010; Altun ve Cengiz, 2012). Tüm bu ifadeler okul gelişiminin öğretmen ve öğrencilerin gelişimi ile doğru orantılı olduğunu göstermektedir.

Okul gelişimi, bir okulun nasıl geliştirileceği, hangi kaynakların kimler tarafından ve nasıl kullanılacağının değerlendirilmesini yaparak okulun gideceği yönü belirlemekte, okuldaki uygulamalar için bir çerçeve oluşturmaktadır (Şahin, 2013). Bu nedenle planlama okul gelişimi için önemli bir unsurdur. Nitekim, Mintrop ve Maclellan (2002), planlamanın etkili okullarda gerçekleştirilen okul geliştirme sürecinin anahtar unsuru olduğunu belirterek planlamanın önemini vurgulamıştır. Jones (1996) okul gelişim planı öğelerinin; program, kaynaklar, personel gelişimi, fiziksel çevre, örgütleme ve yönetim olduğunu belirtmiştir. Balkar (2010) ise, okul gelişim planı kapsamında okul gelişimine dışarıdan katkının olması gerektiği ifade ederek, okul-çevre ilişkilerinin geliştirilmesi ve bunun içinde de velilerin, yardımseverlerin ve diğer kuruluşların yardımının gerektiğini vurgulamıştır.

Öğrencilerin eğitsel gereksinimleri okul geliştirme çalışmalarının temelini oluşturmalıdır. Okullar farklı niteliklere sahip birçok insanı bir araya getiren, diğer kurumlardan farklı bir yapıya sahip örgütler olduğundan, okul geliştirme tüm okul toplumu üyelerinin iş birliği içinde çalışmalarını gerektirmektedir (Gökyer, 2011). Şahin (2006), bir okulun geliştirilmesi için, okulun fiziki yapısının ve donanımının öğrencilerin, öğretmenlerin ve okulla ilişkili diğer bireylerin gereksinimlerini karşılayacak biçimde düzenlenmesi gerektiğini ve bu noktada okul yöneticilerinin anahtar role sahip olduğunu ifade etmiştir. Dolayısıyla bir okulu geliştirmek için yöneticilerin, okulda görevli tüm personelin ve öğrencilerin gelişimini sağlayan, çalışanları destekleyen ve işlerini kolaylaştıran, veliler ve okulla ilişkisi olan paydaşlar arasında iş birliği ve koordinasyon sağlayan bir kişi konumunda olmaları gerekmektedir. Çünkü okullarda çağın gereklerine uygun olarak yapılacak yenilik ve değişim faaliyetlerinde, tüm paydaşların karar alma sürecinde aktif rol alması, okulun mevcut kapasitesini güçlendirecek planlı ve sürekli gelişimin sağlanması önemli görülmektedir. Bu gelişimin sağlanması için ise, madde ve insan kaynakların verimli bir şekilde kullanılması ve koordine edilmesi gerekmekte, 
bu noktada en önemli görev okul yöneticilerine düşmektedir. Bu bağlamda araştırmada, okul yöneticilerinin okul gelişim modeline (OGM) ilişkin görüşlerinin belirlenmesi amaçlanmıştır.

\section{Yöntem}

\section{Araştırma Modeli}

Bu çalışma, nitel araştırma desenlerinden durum çalışması yöntemi ile yürütülmüştür. Bir konu ile ilgili ayrıntılı incelemenin yapıldığı durum çalışması, araştırmacıya konu hakkında derinlemesine inceleme firsatı sunmaktadır (Yıldırım ve Şimşek, 2013). Çalışmada da okul yöneticilerinin okul gelişim modeli hakkındaki görüşlerinin alınması amacıyla durum çalışmasının kullanılmasına karar verilmiştir.

\section{Çalışma Grubu}

Araştırmanın çalışma grubu ilkokullarda görev yapan yöneticilerden oluşmaktadır. Çalışma grubunu oluşturan yöneticiler, amaçlı örneklem yöntemi ile seçilmiştir. Amaçlı örneklem, nitel araştırmalarda kullanılan örnekleme tekniklerinden biri olup; belli amaçlara dayalı olarak araştırma sorularının cevaplanmasiyla ilgili birimlerin (bireyler, gruplar, vb.) seçilmesi olarak tanımlanmaktadır (Teddlie ve Yu, 2007). Ayrıca yöneticilerin, okul gelişim modeli hakkında bilgi sahibi olmaları/çalışmalar yapmaları ve bulundukları okulda en az bir yıl süreyle görev yapıyor olmaları ölçüt olarak alınmıştır. Katılımcı sayısının belirlenmesinde, verilerin doygunluğa ulaştığı, başka bir ifadeyle, yeni katılımclardan toplanan verilerin eski verilerden elde edilen bulguların tekrarı olmaya başladığı, yeni kod ve temaların ortaya çıkmadığı durumlar göz önünde bulundurulmuştur. Çalışma grubu, Gaziantep ili Şahinbey ve Şehitkamil ilçelerindeki ilkokullarda görev yapan 9 okul müdürü, 12 okul müdür yardımcısı olmak üzere toplam 21 okul yöneticisinden oluşmaktadır. Çalışma grubundaki yöneticilerin 16'sı erkek, 5'i ise kadındır. Yöneticilerin 9'u 31-40 yaş arasında, 12'si 41 ve üzeri yaşta bulunmaktadır. Yöneticilikteki kıdem bakımından 4'ü 1-5 yıl, 7'si 6-10 yıl, 10'u ise 11 ve üzeri kıdeme sahiptir. Yöneticilerin 17'si lisans, 4 'ü yüksek lisans mezunudur. 


\section{Veri Toplama Aracı}

Veriler, yarı yapılandırılmış görüşme formu aracılığı ile toplanmıştır. Yarı yapılandırılmış görüşme tekniğinde, araştırmacı sormayı planladığı soruları içeren görüşme protokolünü hazırlamaktadır (Türnüklü, 2000). Bu yöntemde görüşmeci önceden hazırladığı konu veya alanlara bağlı kalarak önceden hazırlanmış soruları sormanın yanı sıra daha ayrıntılı bilgi edinmek amaciyla ek sorular sorma özgürlüğüne sahiptir (Yıldırım ve Şimşek, 2013).

Bu kapsamda, okul gelişim modeli ile ilgili olarak okul yöneticilerine yönelik olarak yarı yapılandırılmış bir görüşme formu hazırlanmıştır. Soruların hazırlanması aşamasında, öncelikle ilgili alan yazın taraması yapılarak konu ile ilgili çeşitli ulusal (Altun ve Bebek, 2016; Balkar, 2010; Gökyer, 2011; Şahin, 2006; Şahin, 2013) ve uluslararası çalışmalar (Anfara, Patterson, Buehler ve Gearity, 2006; Heck ve Hallinger, 2010; Hopkins, 2004; Jones, 1996; Mintrop ve Maclellan, 2002; Smylie, Conley ve Marks, 2002) incelenmiştir. Bu sayede okul gelişim modeli hakkında kapsamlı bilgilere ulaşıldıktan sonra, araştırmacılar tarafından görüşme formunda yer alması düşünülen maddeler belirlenmiştir. Maddelerin kapsam geçerliliği ve çalışmanın amacına uygunluğunun değerlendirilmesi için Gaziantep Üniversitesi Eğitim Fakültesinde görev yapan üç öğretim üyesi, ifadelerin dil açısından incelenmesi için ise iki Türkçe öğretmeni ve eğitim yönetimi alanında yüksek lisans ve doktora yapan iki yöneticinin görüş ve önerileri alınmıştır. Üç yönetici ile yapılan pilot uygulama sonucunda yöneticilerden gelen tavsiyeler doğrultusunda iki soru anlaşılabilirlik açısından düzeltilmiş, daha açık bir şekilde ifade edilmiştir. Bu aşamalar sonucunda forma son şekli verilmiş ve görüşme soruları çalışma grubundaki yöneticilere yöneltilmiştir. Görüşme formundaki sorular aşağıda yer almaktadır.

1. Okul gelişim modeli hakkındaki düşünceleriniz nelerdir?

2. Okul gelişim modelinde, okula yönelik hedefler belirlenirken ölçütler neler olmalıdır?

3. Size göre bir okulu geliştirmek için neler yapılmalıdır?

- Eğitim-öğretim ile ilgili olarak neler yapılmalıdır?

- Personel ile ilgili olarak neler yapılmalıdır?

4. Okul gelişim planı hazırlanırken nelere dikkat edilmelidir?

- Okul gelişim planlarının okulda uygulanabilirliğini arttırmak için neler yapılmalıdır? 
- Paydaşların (yönetici, öğretmen, veli vb.) okul gelişim planındaki rolü/katkısı nedir?

5. Okul gelişim modeli uygulama sürecinde, okulunuzun önündeki engellerin neler olduğunu ve bu engelleri ortadan kaldırmak için neler yapılması gerektiğini düşünüyorsunuz?

6. Okul gelişim modeli uygulama sürecinde, okulunuzun önündeki firsatların neler olduğunu ve okulunuzun bu firsatlardan nasıl yararlandiğını düşünüyorsunuz?

7. Okul gelişim modeli sürecinin değerlendirilmesinde hangi kriterlere dikkat edilmeli ve değerlendirme kimler tarafından yapılmalıdır?

\section{Verilerin Toplanması}

Nitel bir araştırmada amaç, bilgilerin genellenmesinden ziyade özellikle spesifik açıklamaların yapılmasıdır (Creswell, 2016). Bu bağlamda, çalışma grubunu oluşturan 21 yönetici ile yarı yapılandırılmış görüşmeler yapılmıştır. Görüşmeler okul müdürlerinin bilgisi dâhilinde yöneticilerin görev yaptıkları okullarda gerçekleştirilmiştir. Görüşme sürecinin etkileşim içerisinde gerçekleştirilmesi ve daha sağlıklı cevaplar alınabilmesi amacıyla katılımcllara okul gelişim modeli hakkında ön bilgilendirme yapılmıştır. Görüşmelerde, görüşme yapılan yerin fiziki şartları kontrol edilerek, katılımcılarla rahat ve sessiz bir ortamda görüşme yapılmasına özen gösterilmiştir. Katılımcılara gerekli açıklamalar yapıldıktan sonra gönüllülük esasına bağlı olarak, yapılan görüşmelerin 3'ü yazılı olarak, 18'i ise ses kayıt cihazı ile kayıt altına alınmıştır. Görüşmeler araştırmacılar tarafından randevular alınarak yaklaşık 35-45 dakika arasında değişen sürelerde yüz yüze gerçekleştirilmiştir.

\section{Verilerin Analizi}

Yapılan görüşmelerden elde edilen verilerin çözümlenmesinde, betimsel analiz ve içerik analizi kullanılmıştır. Betimsel analizde, veriler, önceden belirlenen temalara göre özetlenerek yorumlanmakta, bireylerin görüşlerini çarpıcı bir şekilde yansıtmak amacıyla doğrudan alıntılara yer verilmektedir (Yıldırım ve Şimşek, 2013). Nitel araştırmalarda yaygın olarak kullanılan bir teknik olan içerik analizinde ise (Stemler, 2001) araştırmacının, nelerin bir 
örüntü oluşturacağı, nelerin bir tema teşkil edeceği ve bu yapının nasıl isimlendirileceği ile ilgili karar vermesi gerekmektedir (Patton, 2014). İçerik analizi, verilerin incelenerek anlamlı bölümlere ayrılması ve bu bölümlerin kavramsallaştırılması "verilerin kodlanması", kodlardan faydalanılarak verilerin genel düzeyde açıklanması ve kodların belli kategorilerde bir araya getirilmesi "temaların bulunması", verilerin okuyucunun anlayacağ biçimde kodlara ve temalara göre düzenlenmesi "verilerin kodlara ve temalara göre düzenlenmesi ve tanımlanması" ve toplanan veriler arasındaki ilişkilerin açıklanması "bulgularm sunulması ve yorumlanması" olmak üzere dört aşamada yapılmaktadır (Creswell vd., 2007; Yıldırım ve Şimşek, 2013).

Bu doğrultuda, ilk aşamada ses kayıtları ve görüşme formalarındaki veriler bilgisayar ortamına aktarılarak ham veri metinleri oluşturulmuştur. Veriler, MAXQDA 2018 nitel veri analizi programı kullanılarak analiz edilmiştir. Kodların belirlenmesinde literatürde kullanılan kavramlar ve görüşmeler sonucu ortaya çıkan veriler göz önünde bulundurulmuştur. Kavramlar arasındaki benzer ve ortak yönler dikkate alınarak tematik kodlama yapılmış ve temalar oluşturulmuştur. Tematik kodlama esnasında belirlenen temalardaki kavramların birbirleriyle anlamlı bir bütün oluşturmasına dikkat edilmiştir. Bu bağlamada, temalar ve kodlar birbirleriyle ilişkili olacak şekilde düzenlenerek, çalışmanın amacı doğrultusunda yorumlara ve düşüncelere yer verilmiştir. Katılımcılara ait görüşleri örnekleyen ifadelere yer verilmesine özen gösterilmiştir. Verilen ifadenin öncesinde ya da sonrasında görüşün devam ettiğini belirtmek amacıyla, [...] işareti kullanılmıştır. Yöneticiler, K1: Katılımcı 1, K2: Katılımcı 2, K3: Katılımcı 3, ... şeklinde kodlanmıştır.

\section{Geçerlik ve Güvenirlik Çalışmaları}

Çalışmada geçerlik kapsamında, inandırıcılık ve aktarılabilirlik; güvenirlik kapsamında ise, tutarlılık ve tekrar edilebilirlik (Erlandson vd., 1993, akt. Yıldırım ve Şimşek, 2013) çalışmaları yapılmıştır. İnandırııılık, gözlenen ilişkinin nedensel olduğuna dair araştırmacının çıkarımının doğruluğu ile ilgilidir (Christensen vd., 2015). İnandırıcılıkla ilgili olarak, katılımcılarla yapılan görüşmeler mümkün olduğunca uzun süreli tutularak ayrıntılı bilgi alınmasına dikkat edilmiştir. Buna ek olarak, okul gelişim modeli ve nitel araştırma yöntemleri konusunda uzmanlarla birlikte, verilerin toplanması, analizi ve so- 
nuçlarına yönelik değerlendirmeler yapılmıştır. Son olarak, bilgisayar ortamında yazıya aktarılan veriler, katılımcılara okutularak kendi görüşlerini yansıtıp yansıtmadığı teyit edilmiştir. Aktarılabilirliğin sağlanmasına amacı ile, araştırma sonucunda elde edilen veriler, kavram ve temalara göre düzenlenmiş (Yıldırım ve Şimşek, 2013); ayrıntılı betimlemeler yapılarak, katılımcıların görüşlerinden doğrudan alıntılara yer verilmiştir.

Güvenirlik çalışmaları kapsamında yapılan tutarllık, çalışma sürecinin zaman, araştırmacı ve mekân karşısında görece sabit olmasıdır (Miles ve Huberman, 2015). Tutarlığın sağlanması amacıyla, verilerin kodlanma sürecinde yapılan kontrollerin yeterliliği ve veri analizlerde bu kodların uygun temalar altında birleştirilmesine dikkat edilmiştir. Ayrıca, verilerin çözümlenmesinde bağımsız kodlayıcılar arasındaki tutarlılık sağlanmak amacıyla alanda uzman 4 kişinin görüşüne başvurulmuştur. Veriler, nitel veri analiz programlarından biri olan MAXQDA 2018 ile analiz edilmiştir. Miles ve Huberman'ın (1994) formülü (Güvenirlik = görüş birliği/görüş birliği + görüş ayrllığ1 X 100) kullanılarak yapılan hesaplamalarda kodlayıcılar arasındaki görüş birliği oranı 0.94 olarak belirlenmiştir. Son olarak, tekrar edilebilirlik ile ilgili araştırmacının alabileceği en önemli önlem araştırmanın temel aşamalarının yanı sıra araştırma sürecindeki konumu ve yaklaşımı konusunda ayrıntılı ve açı bilgi vermektir (Yıldırım ve Şimşek, 2013). Bu doğrultuda, görüşme süreci, analiz süreci ve elde edilen sonuçların sunumuyla ilgili mümkün olduğunca ayrıntılı açıklamalara yer verilmesine dikkat edilmiştir.

\section{Bulgular}

\section{Okul Gelişim Modelinin Tanımına İlişkin Bulgular}

Araştırmada yöneticilere ilk olarak "Okul gelişim modeli hakkındaki düşünceleriniz nelerdir?" sorusu yöneltilmiştir. Bu soruya yönelik yapılan tematik ve kavramsal kodlamalar aşağıdaki Tablo 1'de yer almaktadır. 
Tablo 1. Okul Gelişim Modeli'nin Tanımına Ait Tematik ve Kavramsal Kodlamalar

\begin{tabular}{lll}
\hline \multirow{2}{*}{ Tema } & Kavramsal Kodlamalar & $f$ \\
\hline & Ortak karar alma & 7 \\
\cline { 2 - 3 } & Okulu ilerletme & 6 \\
\cline { 2 - 3 } & Planlı ve sistemli çalışmalar & 5 \\
\cline { 2 - 3 } & Akademik başarını arttırılması & 5 \\
\cline { 2 - 3 } & Eğitim-öğretimi geliştirme & 2 \\
\cline { 2 - 3 } & Okul çevre iliş̧kisinin geliştirilmesi & 2 \\
\cline { 2 - 3 } & Tüm paydaşların geliştirilmesi & 1 \\
\cline { 2 - 3 } & Fiziki yapının iyileştirilmesi & 1 \\
\cline { 2 - 3 } & Okulun geleceğini planlama & 1 \\
\cline { 2 - 3 } & Okulun vizyonunu gerçekleştirme & \\
\hline
\end{tabular}

Tablo 1 incelendiğinde, okul gelişim modelinin tanımı ile ilgili yönetici görüşlerinin sıklık sırasına göre, ortak karar alma $(f=7)$, okulu ilerletme $(f=6)$, planlı ve sistemli çalışmalar $(f=5)$, akademik başarının arttırılması $(f=5)$, eğitim-öğretimi geliştirme $(f=3)$, okul-çevre ilişkisinin geliştirilmesi $(f=2)$, Tüm paydaşların geliştirilmesi $(f=2)$, fiziki yapının iyileştirilmesi $(f=1)$, okulun geleceğini planlama $(f=1)$ ve okulun vizyonunu gerçekleştirme $(f=1)$ şeklinde ifade edildiği görülmektedir. Yöneticilerin okul gelişim modeline ilişkin yaptıkları tanımlarda en çok ortak karar alma ve okulu ilerletme kavramlarına vurgu yapıldığı görülmektedir. Bu konuda görüş belirten yöneticilerden biri düşüncelerini şu şekilde ifade etmiştir: Okul gelişim modeli, okullarımızın mevcut durumlarm gözden geçirip, ihtiyaç ve hedeflerini belirleyebildiği ve uygulamaya koyabilmesine imkân sağlayan, vizyonunu bir plan dahilinde uygulamasina imkân tanıyan bir çalışmadır (K11).

Okul gelişim modelinin okulu geliştirmek için yapılan faaliyetler olduğunu belirten bir yönetici okul gelişim modelini; Okulun yönetim, eğitim ve öğretim süreçlerini geliştirerek, öğrencilerin başarılarını arttırmayı amaçlayan sistematik bir yaklaşımdır (K15) şeklinde ifade ederken; diğer bir yönetici ise, Okul gelişim modeli, okullarda hedeflenen çalışmalarn, planlı ve sistemli bir şekilde, okulun bütünün gelişim sürecine katılmasını sağlayarak, kendine eş değer kurumlardan daha iyi duruma getirilmesinin să̆lanmasıdır. (K5) şeklinde görüş belirtmiştir. Planlamanın önemine dikkat çeken ve bu yönde görüş belirten yöneticilerden biri de okul gelişimi modelini; Okulun geleceğinin planlanmasma yönelik olarak yaptlan faaliyetlerin tümüdür (K12) biçiminde tanımlamıştır. 


\section{Hedef Belirleme Ölçütlerine İlişkin Bulgular}

Yöneticilerin "Okul gelişim modelinde, okula yönelik hedefler belirlenirken ölçütler neler olmalıdır?" sorusuna yönelik görüşlerinden ortaya çıkan tema ve kodlar aşağıdaki Tablo 2'de sunulmuştur.

Tablo 2. Hedef Belirleme Ölçütleri'ne Ait Tematik ve Kavramsal Kodlamalar

\begin{tabular}{|c|c|c|}
\hline Tema & Kavramsal Kodlamalar & $f$ \\
\hline \multirow{13}{*}{ 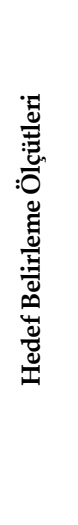 } & Uygulanabilirlik & 6 \\
\hline & Okul çevresinin durumu & 6 \\
\hline & Okulun fiziki yapısı/donanımı & 5 \\
\hline & Sosyo-ekonomik yapı & 5 \\
\hline & Öğrenci seviyesi & 5 \\
\hline & Okulun kaynakları & 3 \\
\hline & Personel yeterlilikleri & 3 \\
\hline & Veli profili & 2 \\
\hline & Okulun güçlü ve zayıf yönleri & 2 \\
\hline & İlgi ve ihtiyaçlar & 1 \\
\hline & Okulun kadro durumu & 1 \\
\hline & Milli Eğitimin amaçları & 1 \\
\hline & Okulun misyonu/vizyonu & 1 \\
\hline
\end{tabular}

Tablo 2'de görüldüğü üzere, hedef belirleme ölçütleri ile ilgili yönetici görüşleri, uygulanabilirlik $(f=6)$, okul çevresinin durumu $(f=6)$, okulun fiziki yapısı/donanımı $(f=5)$, sosyo-ekonomik yapı $(f=5)$, öğrenci seviyesi $(f=5)$, okulun kaynakları $(f=3)$, personel yeterlilikleri $(f=3)$, veli profili $(f=2)$, okulun güçlü ve zayıf yönleri $(f=2)$, ilgi ve ihtiyaçlar $(f=1)$, okulun kadro durumu $(f=1)$, Milli Eğitimin amaçları $(f=1)$ ve okulun misyonu/vizyonu şeklindedir. Bu konuda görüş belirten ve hedeflerin ulaşılabilir olması gerektiğine vurgu yapan yöneticilerden biri düşüncelerini, Hedefler belirlenirken, özellikle okulun çevresi, veli ve öğrenci profili dikkate alınmalıdır. Okulun mevcut durumu (materyal, fiziki yapı vb.) dikkate alınarak araç-gereç temini sağlanarak, ulaşılabilir hedefler konulmalıdır (K6) şeklinde ifade ederken; çevresel şartların göz önünde bulundurulması ve hedef belirlemede ölçüt olarak alınması gerektiğine vurgu yapan bir yönetici ise, Hedefler, okul çeoresinin durumu, sosyo-ekonomik yapı, ilgi, ihtiyaçlar ve insan kaynağımm uygunluğuna göre belirlenmelidir (K1) görüşünü belirtmiştir. 
Okulun gerek fiziki şartlarının ve güçlü/zayıf yönlerinin gerekse personel yeterliliklerinin göz önünde bulundurulması ve hedeflerin buna göre belirlenmesi gerektiğini ifade eden yöneticilerden birinin görüşü şu şekildedir: Her bir okulun var olan imkanları göz önünde bulundurulup, ulaşılabilir hedeflere yer verilmelidir (K19). Ölçütlerin belirlenmesinde okulun bulunduğu mevcut durumun ve çevresel koşulların dikkate alınması gerektiği yönünde görüş belirten diğer bir yönetici ise düşüncelerini, Bu ölçütlerin belirlenmesinde dikkate alımması gereken şey, çeore şartları dikkate alınarak okulun iyileştirilmesi çalışmalarıdır. Veli ve öğrencilerin okul ile ilişkisi ve öğrenci başarısı ölçüt olarak alınmalıdır. Her okul birbirinden fakh özelliklere sahip olduğu için ölçütler okullara göre değişiklik göstermektedir (K21) şeklinde ifade etmiştir.

\section{Okul Gelişimi İçin Yapılması Gerekenlere İlişkin Bulgular}

Çalışmada üçüncü soru olarak yöneticilere, "Size göre bir okulu geliştirmek için neler yapılmalıdır?" sorusu yöneltilmiştir. Bu soruyla ilgili yönetici görüşleri "eğitim-öğretim" ve "personel" olmak üzere iki temada toplanmış, aşağıdaki Tablo 3'de sunulmuştur.

Tablo 3. Okul Gelişimi İçin Yapılması Gerekenlere Ait Tematik ve Kavramsal Kodlamalar

\begin{tabular}{|c|c|c|}
\hline Tema & Kavramsal Kodlamalar & $f$ \\
\hline \multirow{9}{*}{ 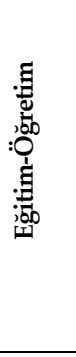 } & Öğrencilerin gelişimini sağlama & 5 \\
\hline & Fiziki şartları/ortamı iyileştirme & 5 \\
\hline & Okul aile iş birliğini sağlama & 3 \\
\hline & Eğitim sisteminin revize edilmesi & 3 \\
\hline & İş birliği ve güven ortamı oluşturma & 2 \\
\hline & Dezavantajlı öğrencilere destek olma & 1 \\
\hline & Çevreden destek alma & 1 \\
\hline & Sosyal faaliyetlerin sayısını arttırma & 1 \\
\hline & Öğrenci mevcutlarını azaltma & 1 \\
\hline \multirow{5}{*}{ 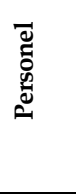 } & Öğretmen yeterliliğini geliştirme & 11 \\
\hline & Başarılı öğretmenlere ödül verme/motive etme & 8 \\
\hline & Hizmet içi eğitime katılıma teşvik etme & 5 \\
\hline & Uygulamaya yönelik eğitimler verme & 2 \\
\hline & Kadrolu öğretmen istihdamı & 1 \\
\hline
\end{tabular}

Tablo 3 incelendiğinde, okul gelişimi için eğitim-öğretim ile ilgili olarak yapılması gerekenler sıklık sırasına göre, öğrencilerin gelişimini sağlama 
$(f=5)$, fiziki şartları/ortamı iyileştirme $(f=5)$, okul-aile iş birliğini sağlama $(f=3)$, eğitim sisteminin revize edilmesi $(f=3)$, iş birliği ve güven ortamı oluşturma $(f=2)$, dezavantajlı öğrencilere destek olma $(f=1)$, çevreden destek alma $(f=1)$, sosyal faaliyetlerin sayısını arttırma $(f=1)$, öğrenci mevcutlarını azaltma $(f=1)$ şeklindedir.

Eğitim-öğretim temasında en çok öğrencilerin gelişimini sağlama ve okulun fiziki şartlarının iyileştirilmesi konusunda görüş belirtilmiştir. Okulun gelişiminin öğrencilerin gelişimi ile sağlanacağını belirten yöneticilerden biri bu konudaki düşüncesini; Öğrenciler ezberden uzaklaştırılarak, olaylar arasında muhakeme kurmalarn sağlanmalı, araştırı öğrenen kişiler haline gelmeleri için eğitim-öğretim faaliyetleri düzenlenmelidir (K5) şeklinde ifade ederken; benzer doğrultuda diğer bir yönetici ise, Öğrencilerin özel yetenek ve becerilerini keşfetmelerine yönelik olarak çalışmalar yapılmalıdır (K2) görüşünü belirterek eğitim sisteminin bu yönde revize edilmesi gerektiğini vurgulamıştır.

Okul gelişimi için fiziki şartların uygun olması gerektiği konusunda görüş belirten yöneticilerden biri [...] Fiziki şartlarm iyileştirilmesi, ders araç-gereçlerinin yeterliliği, öğretmeler arasında güvenli bir öğrenme ve iletişim ortamını oluşturulması gereklidir (K1) ifadesini kullanırken; sınıf mevcutlarının kalabalık olmasını ve sınıfların fiziksel olarak yeterli donanıma sahip olmadığını belirten diğer bir yönetici ise düşüncelerini, Yapılan faaliyetler çă̆daş eğitim seviyesine uygun olmalıdır. Sinıflarm kalabalı olmaması, fiziksel donanımin yeterli olması gerekir (K7) şeklinde ifade etmiştir.

Personel ile ilgili olarak okul gelişimini sağlamak için yapılması gerekenler, öğretmen yeterliliğini geliştirme $(f=11)$, başarılı öğretmenlere ödül verme/motive etme ( $f=8)$, hizmet içi eğitime katılıma teşvik etme $(f=5)$, uygulamaya yönelik eğitimler verme $(f=2)$ ve kadrolu öğretmen istihdamı $(f=1)$ şeklinde sıralanmaktadır. Bu konuda yöneticilerden birinin görüşleri şu şekildedir: Üniversitede verilen akademik bilgi ile okuldaki gerçek yaşantı arasında fark vardır. Bundan dolayı okullarda nitelikli öğretmen yetiştirilmesi gerekir. Pedogojik formasyon yönünden öğretmenlerin geliştirilmesi gerek. Mevcuttaki öğretmenlere okulun işleyişi, sistemi ve yönetmelikler hakkında bilgi verilmesi gerekiyor (K21). Motivasyonun önemli olduğunu ve öğretmenlerin motive edilmesinin eğitim-öğretim faaliyetlerinin daha verimli bir şekilde gerçekleşmesine katk1 sağlayacağ1 yönünde görüş belirten bir yönetici de; Personelin okulu, öğrenciyi 
severek işini yapması için, teşvik edici ve başarıyı ödüllendirici çalışmalara ă̆ırlık verilmeli, toplantılar olumlu bir havada geçirilmeli, örnek davranışlar takdir edilip ödüllendirilmelidir (K11) ifadesini kullanmıştır.

\section{Okul Gelişimin Modelinin Planlamasına İlişkin Bulgular}

Yöneticilerin "Okul gelişim modeli planı hazırlanırken nelere dikkat edilmelidir?" sorusuna verdikleri cevaplara yönelik yapılan tematik ve kavramsal kodlamalar aşağıdaki Tablo 4'te yer almaktadır:

Tablo 4. Okul Gelişim Modelinin Planlanmasına Ait Tematik ve Kavramsal Kodlamalar

\begin{tabular}{|c|c|c|}
\hline Tema & Kavramsal Kodlamalar & $f$ \\
\hline \multirow{6}{*}{ 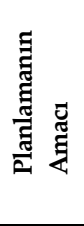 } & Hedefe ulaşma & 6 \\
\hline & Başarıyı arttırma & 3 \\
\hline & Okulu geliştirme & 3 \\
\hline & Kılavuzluk yapma & 2 \\
\hline & Düzen sağlama & 2 \\
\hline & Okulun ihtiyaçlarını giderme & 1 \\
\hline \multirow{8}{*}{ 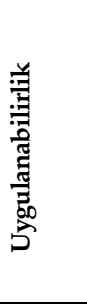 } & Ulaşlabilir hedefler koyma & 8 \\
\hline & Tüm paydaşların desteğini sağlama & 7 \\
\hline & Okulun maddi durumunu dikkate & 4 \\
\hline & Öğretmenleri motive etme & 3 \\
\hline & Çevresel şartları dikkate alma & 2 \\
\hline & Okulun fiziki şartlarını uygun hale getirme & 2 \\
\hline & Faaliyetleri denetleme & 1 \\
\hline & İhtiyaçları karşılamaya yönelik olma & 1 \\
\hline \multirow{4}{*}{ 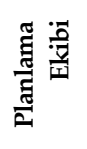 } & Okul idaresi & 18 \\
\hline & Öğretmenler & 17 \\
\hline & Okul-aile birliği başkanı & 8 \\
\hline & Sivil toplum kuruluşları (STK) & 3 \\
\hline
\end{tabular}

Tablo 4'de görüldüğü üzere, okul gelişiminin planlanmasına ilişkin yönetici görüşleri, "planlamanın amacı", "uygulanabilirlik" ve "planlama ekibi" olmak üzere üç tema altında toplanmıştır. Planlamanın amacı teması sırasıyla, hedefe ulaşma $(f=6)$, başarıyı arttırma $(f=3)$, okulu geliştirme $(f=3)$, kılavuzluk yapma $(f=2)$, düzen sağlama $(f=2)$ ve okulun ihtiyaçlarını giderme $(f=1)$ şeklinde kodlardan oluşmaktadır. Planlamanın amacı ile ilgili olarak yöneticilerden biri; Plansız bir gelişim düşünülemez. Öncelikle eksiklikler ve ihtiyaçlar be- 
lirlenmeli, sonra yapılacak çalışmalar bir sıraya konulmalı ve uygulanması takip edilmeli ve değerlendirilmeli ki başarnya ulaşılabilsin (K12) şeklinde görüş belirtirken; diğer bir yönetici ise, Çalışmalarm zamanında yapılması ve sonuç alınması için planlama önemlidir (K15) görüşünü ifade ederek okulun gelişiminin sağlanmasında planlamanın önemi ve gerekliliği vurgulanmıştır.

Yöneticiler planlama yapılması gerektiğini belirtirken aynı zamanda yapılan planların uygulanabilir olması gerektiğini de ifade etmişlerdir. Bu konuda görüş belirten yöneticilerden biri; Planlar, her şeyden önce okulun şartlarina uygun hazırlanmalı ve tüm paydaşlar planların uygulanabilirliğine inandırlmalıdır (K18) ifadesini kullanırken; benzer doğrultuda başka bir yönetici de Planı hazırlarken gerçekçi olmak lazım. Planlarn yazıya dökülmekten ziyade uygulanabilirliği ön plana çıkarlmalıdır (K2) şeklinde görüş belirtmiştir.

Çalışmaya katılan yöneticilerin çoğu, planlama ekibinde okulla ilgili tüm paydaşların rol alması gerektiğini belirtmiştir. Yöneticilerden birinin bu konudaki görüşü şu şekildedir: Okulla ilişkisi olan herkes planlama ekibinde yer almalıdır. İdareci, öğretmen, öğrenci, veli, okul-aile birliği başkanı (K7). Planlama ekibi ile ilgili görüş belirten bir diğer yönetici ise, Okul idaresi, öğretmen, öğrenci, veli bu ekibin içerisinde yer almalıdır. Okul hayatla ilişkili olduğu için, öğrencinin hayatında yer alan tüm bireyleri temsil eden kişilerin olması gerekir. Planı uygulamada, bahsedilen herkesin bir fikir beyanında bulunması önemlidir. Böylece planın herkes tarafindan belirlenmesi ve kabul edilmesi sağlanır (K1) ifadesini kullanmiştır.

\section{Paydaşların Okul Gelişim Planındaki Rolüne İlişkin Bulgular}

Planlama ile ilgili olarak yöneticilere sorulan diğer bir soru "Paydaşlarm (yönetici, öğretmen, veli vb.) okul gelişim planındaki rolü/katkısı nedir?" şeklindedir. $\mathrm{Bu}$ soruya yönelik yapılan tematik ve kavramsal kodlamalara aşağıdaki Tablo 5'te yer verilmiştir.

Tablo 5'te okul gelişim planında yöneticilerin sırasıyla, liderlik yapma $(f=4)$, çalışanlar arasında koordinasyon sağlama $(f=3)$ ve iletişim ortamı oluşturma $(f=3)$; öğretmenlerin, uygulama $(f=8)$, fikir üretme $(f=2)$ ve destekleme $(f=1)$, velilerin ise faaliyetleri destekleme $(f=5)$ ve maddi katkıda bulunma $(f=2)$ rolü bulunduğu görülmektedir. Yöneticilerden biri düşüncelerini, Yönetici, paydaşları bir araya getirip koordinasyon sağlar. Öğretmen, planlama, hedefbelirleme ve uygulama aşamasında yer alır. Okul-aile, finansman ile ilgili işlere bakma ve veliler 
arasında koordinasyon sağlamada görevlidir (K4) şeklinde ifade ederken; diğeri ise Yöneticiler, okul gelişim planının oluşumunda yol göstericidir. Çalışanları teşvik ederek, kurum kültürü̈ oluşması için çalışrlar. Öğretmenler, bu süreçte fikir üretici ve uygulayıcı, veliler ise destekleyici durumdadırlar (K11) görüşünü belirtmiştir

Tablo 5.Paydaşların Okul Gelişim Planındaki Rolüne Ait Tematik ve Kavramsal Kodlamalar

\begin{tabular}{|c|c|c|}
\hline Tema & Kavramsal Kodlamalar & $f$ \\
\hline \multirow{3}{*}{ 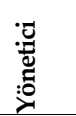 } & Liderlik yapma & 4 \\
\hline & Çalışanlar arasında koordinasyon sağlama & 3 \\
\hline & İletişim ortamı oluşturma & 3 \\
\hline \multirow{3}{*}{ 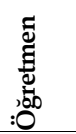 } & Uygulama & 8 \\
\hline & Fikir üretme & 2 \\
\hline & Destekleme & 1 \\
\hline \multirow{2}{*}{$\frac{\pi}{0}$} & Faaliyetleri destekleme & 5 \\
\hline & Maddi katkıda bulunma & 2 \\
\hline
\end{tabular}

\section{Okul Gelişim Planının Uygulanma Sürecine İlişkin Bulgular}

Uygulama süreci ile ilgili yöneticilere okul gelişim planını uygulamada karşılaşılan engeller ve bu engellere karşı çözüm önerileri ile okulun sahip olduğu firsatlar ve okulun bu firsatlardan yararlanma durumuna yönelik iki soru yöneltilmiştir.

\section{Uygulama sürecinde karşılaşılan engeller ve çözüm önerilerine ilişkin bulgular}

Yöneticilere sorulan "Uygulama sürecinde, okulunuzun önündeki engellerin neler olduğunu ve bu engelleri ortadan kaldırmak için neler yapılması gerektiğini düşünüyorsunuz?" sorusuna yönelik ortaya çıkan tema ve kodlar aşağıdaki Tablo 6'da sunulmuştur. 
Tablo 6. Uygulama Sürecinde Karşılaşılan Engeller ve Çözüm Önerilerine Ait Tematik ve Kavramsal Kodlamalar

\begin{tabular}{|c|c|c|}
\hline Tema & Kavramsal Kodlamalar & $f$ \\
\hline \multirow{9}{*}{ 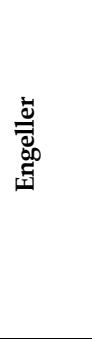 } & Kaynak yetersizliği & 13 \\
\hline & Veli desteğinin yetersiz olması & 9 \\
\hline & Öğrenci sayısının kalabalık olması & 3 \\
\hline & Öğretmenlerin yenilik ve değişime kapalı olması & 3 \\
\hline & Okulun fiziki yapısının yetersizliği & 3 \\
\hline & Çalışanlar arasındaki iletişim kopukluğu & 2 \\
\hline & Ulaşılamayacak hedefler belirlenmesi & 2 \\
\hline & Yabancı uyruklu öğrenciler & 1 \\
\hline & Öğrenci profili & 1 \\
\hline \multirow{9}{*}{ 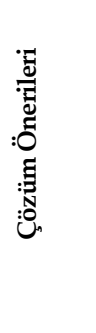 } & Okullara yeterli kaynak verilmesi & 9 \\
\hline & Velilerin bilinçlendirilmesi & 7 \\
\hline & Öğretmenlere hizmet içi eğitim verilmesi & 5 \\
\hline & Okulların fiziki yapısının iyileştirilmesi & 4 \\
\hline & Uygulanabilir hedefler belirlenmesi & 3 \\
\hline & Okul/derslik sayısının arttırılması & 2 \\
\hline & Paydaşların bilgilendirilmesi & 1 \\
\hline & Okul-aile birliğinin işlevsel hale getirilmesi & 1 \\
\hline & Çalışanların motivasyonunun arttırılması & 1 \\
\hline
\end{tabular}

Tablo 6'ya göre, okul gelişim planının uygulanması sürecinde karşılaşılan engeller sırasıyla, kaynak yetersizliği $(f=13)$, veli desteğinin yetersiz olması $(f=9)$, ögrenci sayısının kalabalık olması $(f=3)$, öğretmenlerin yenilik ve değişime kapalı olması $(f=3)$, okulun fiziki yapısının yetersizliği $(f=3)$, çalışanlar arasındaki iletişim kopukluğu $(f=2)$, ulaşılamayacak hedefler belirlenmesi $(f=2)$, yabanc1 uyruklu öğrenciler $(f=1)$ ve öğrenci profili $(f=1)$ şeklindedir. Engellerle ilgili olarak kaynak yetersizliği hakkında yöneticilerden biri düşüncelerini, Veli profili, müfredat değişikliği ve kaynaklarnn yeterli olmaması, sınıf mevcutlarının giderek artması (K2) şeklinde ifade ederken; hedef belirleme konusunda sorunlar olduğunu vurgulayan diğer bir yönetici ise, Ulaşılamayacak hedefler belirlenmesi, öğrencilerin hazır bulunuşluk düzeylerinin ve ihtiyaçlarının dikkate alınmaması. Okul gelişim modelinin paydaşlara tam olarak tanıtılmaması, paylaşılmaması gibi sorunlar okul gelişimini engellemektedir (K3) görüşünü belirtmiştir.

Engellerin üstesinden gelmeye yönelik çözüm önerileri ile ilgili yönetici görüşleri, okullara yeterli kaynak verilmesi $(f=9)$, velilerin bilinçlendirilmesi $(f=7)$, öğretmenlere hizmet içi eğitim verilmesi $(f=5)$, okulların fiziki yapısının 
iyileştirilmesi $(f=4)$, uygulanabilir hedefler belirlenmesi $(f=3)$, okul/derslik sayısının arttırılması $(f=2)$, paydaşların bilgilendirilmesi $(f=1)$, okul-aile birliğinin işlevsel hale getirilmesi $(f=1)$ ve çalışanların motivasyonlarının arttırılması şeklinde sıralanmaktadır. Okullara yeterli kaynağın sağlanması gerektiği yönünde görüş belirten yöneticilerden biri düşüncelerini şu şekilde ifade etmiştir: Her konuda yeterli ödenek verilmesi ve yardımcı hizmetler personelinin yeterli sayıda görevlendirilmesini düşünüyorum (K15). Kaynak yetersizliğinin giderilmesi dışında velilere ve öğretmenlere yönelik çalışmalar yapılması gerektiği belirten yöneticilerden biri, Velilere, öğretmenlere, öğrencilere seminerler düzenlenmelidir. Derslik sayısı arttırılması ve tekli eğitime geçilmesi gerekir. Okul aile birliğinin etkin çalışması, yardımsever insanlara ulaşılması, üst birimlerle (il ve ilçe milli eğitim müdürlükleri) ile görüşülmelidir (K1), diğeri ise Okul fiziki olarak geliştirilmeli, öğretmenleri geliştirici eğitimler yapılmalıdır (K17) şeklinde görüş belirtmiştir.

2. Uygulama sürecindeki firsatlar ve firsatlardan yararlanmaya ilişkin bulgular

Yöneticilerin "Uygulama sürecinde, okulunuzun önündeki firsatlarn neler olduğunu okulunuzun bu firsatlardan nasıl yararlandığını düşünüyorsunuz?" sorusu ile ilgili görüşleri aşağıdaki Tablo 7'de yer almaktadır.

Tablo 7. Uygulama Sürecindeki Firsatlar ve Firsatlardan Yararlanmaya Ait Tematik ve Kavramsal Kodlamalar

\begin{tabular}{|c|c|c|}
\hline Tema & Kavramsal Kodlamalar & $f$ \\
\hline \multirow{9}{*}{ 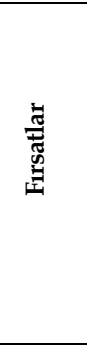 } & Fiziki şartların iyi olması & 9 \\
\hline & Veli profili & 9 \\
\hline & Öğretmen kadrosu & 8 \\
\hline & Öğrenci profili & 3 \\
\hline & Paydaşlar arasındaki iş birliği & 3 \\
\hline & Okulun ulaşımı/konumu & 3 \\
\hline & Çevre desteği & 2 \\
\hline & Sosyo-ekonomik yapı & 1 \\
\hline & Yönetici yeterliliği & 1 \\
\hline \multirow{4}{*}{ 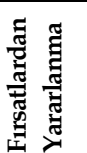 } & Velilerin desteği & 7 \\
\hline & Fiziki alanların etkin şekilde kullanılması & 4 \\
\hline & Sosyal-sportif faaliyetler yapılması & 3 \\
\hline & Öğretmenlerin teknolojiyi etkin kullanması & 2 \\
\hline
\end{tabular}


Tablo 7 incelendiğinde, yöneticilerin okulun önündeki fırsatlarla ilgili görüşlerinin, fiziki şartların iyi olması $(f=9)$, veli profili $(f=9)$, öğretmen kadrosu $(f=8)$, öğrenci profili $(f=3)$, paydaşlar arasındaki iş birliği $(f=3)$, okulun ulaşımı/konumu $(f=3)$, çevre desteği $(f=2)$, sosyo-ekonomik yapı $(f=1)$ ve yönetici yeterliliği $(f=1)$ şeklinde kodlandığı görülmektedir. Bu konuda görüş belirten yöneticilerden biri, Velilerimizin eğitim seviyelerinin yüksek, maddi imkanlarının iyi olması. Öğretmenlerimizin ilgili ve çalışkan olması. Disiplin ve devamsızlk sorunlarmın olmaması (K11), diğeri ise, En büyük firsatımız öğretmenlerimizdir. Aile ortamının oluşturulmuş olması, hesap verebilir, şeffafbir ortamın bulunması bu okul için çok önemli ve en büyük güçtür [...] (K4) ifadesini kullanarak okullarının sahip olduğu firsatların neler olduğunu belirtmişlerdir.

Okulun firsatlardan yararlanma durumları ile ilgili olarak, velilerin desteği $(\mathrm{f}=7)$, fiziki alanların etkin şekilde kullanılması $(f=4)$, sosyal sportif faaliyetlerin yapılması $(f=3)$ ve öğretmenlerin teknolojiyi etkin kullanması $(f=2)$ şeklinde görüş belirtmişlerdir. Yöneticilerden birinin görüşleri şu şekildedir: Veli-okul iş birliği tam anlamda sağlanmaktadır. Bu konuda velilerin ve öğretmenlerin ihtiyaçları belirlenmekte ve bu yönde düzenleme yapılmaktadır (K9).

\section{Okul Gelişimi Sürecinin Değerlendirilmesine İlişkin Bulgular}

Yöneticilere son olarak okul gelişim sürecinin değerlendirilmesi ile ilgili olarak "Okul gelişim sürecinin değerlendirilmesinde hangi kriterlere dikkat edilmelidir?" sorusu sorulmuştur. Yapılan tematik ve kavramsal kodlamalar aşağıdaki Tablo 8'de yer almaktadır:

Tablo 8. Okul Gelişimi Sürecinin Değerlendirmesine Ait Tematik ve Kavramsal Kodlamalar

\begin{tabular}{|c|c|c|}
\hline Tema & Kavramsal Kodlamalar & $f$ \\
\hline \multirow{3}{*}{ :0 } & Hedeflerin gerçekleşme düzeyi & 10 \\
\hline & Akademik başarı & 6 \\
\hline & Okul çevresinin durumu & 4 \\
\hline \multirow{5}{*}{ 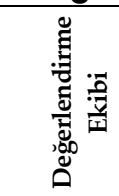 } & Öğretmenler & 16 \\
\hline & Veliler & 13 \\
\hline & Okul idaresi & 12 \\
\hline & Öğrenciler & 5 \\
\hline & Okul dışından uzman bir ekip & 5 \\
\hline
\end{tabular}


Tablo 8'e göre, okul gelişim sürecinin değerlendirilmesi sürecinde kullanılacak ölçütler sırasıyla, hedeflerin gerçekleşme düzeyi $(f=10)$, akademik başarı $(f=6)$ ve okul çevresinin durumu $(f=4)$ şeklindeyken, değerlendirme ekibinde yer alması gereken kişilerin ise, öğretmenler $(f=16)$, veliler $(f=13)$, okul idaresi $(f=12)$, öğrenciler $(f=5)$ ve okul dışından uzman bir ekip $(f=5)$ olduğu görülmektedir. Değerlendirme ölçütleri ile ilgili olarak yöneticilerden birinin görüşü şu şekildedir: Belirlenen hedefler doğru tespit edilmiş mi? Bu hedeflere ulaşılırken firsatlardan yararlanılmış mı? Zayıf yönler gü̈clendirilmiş mi? bunlara dikkat edilmelidir. Bunlara dikkat edilirse, okul gelişim planı doğru hazırlanıp yürütülmüs olur (K17). Değerlendirme ekibine yönelik görüş belirten yöneticilerden biri Değerlendirme ekibinde, okul idaresi, öğretmen, öğrenci, veli, okul-aile birliği yer almalıdır. Okulu oluşturan unsurlar oldukları için (K7) ifadesini, diğeri ise Alanında uzman, yenilikçi, değişimi özümsemiş kişiler yer almahdır (K19) ifadelerini kullanarak değerlendirme ekibinde yer alması gerektiğini düşündükleri kişileri belirtmişlerdir.

\section{Tartışma ve Sonuç}

Okul yöneticilerinin okul gelişim modeline ilişkin görüşlerinin belirlenmesi amaçlandığı bu araştırmada, ilk olarak okul yöneticilerinin okul gelişim modeli hakkında düşüncelerini ortaya koymak amaçlanmıştır. Araştırma sonucunda okul yöneticileri okul gelişim modelini en fazla "Ortak karar alma" olarak yorumlamışlardır. Kuramsal çerçeve incelendiğinde okul geliştirmede ortak karar alma ve iş birliği sürekli vurgulanan önemli unsurdur. Okul geliştirme sürecinde paydaşlar bir ekip ruhuyla çalışmak zorundadır, bu ortamı sağlayabilmenin esas yolu üyelerinin ortak hedefler benimsemeleri ve bunlara yönelebilmeleridir (Gülcan, 2009). Araştırmada okul geliştirme sürecinde okul paydaşları ile özellikle de öğretmenler ile ortak karar alma okul gelişiminde önem arz ettitiği sonucuna ulaşılmıştır. Benzer şekilde Balkar (2010) yaptığı araştırmada, öğretmenlerin okul gelişim planlarının hazırlanması sürecinde aktif bir şekilde rol almaları gerektiği sonucuna ulaşmıştır. Okul gelişim planlarının kapsamında yer alacak konuların belirlenmesinde; öğretmen, öğrenci, veli ve okul çevresinin görüşlerinin alınmasına önem verilmelidir. Ayrıca okul geliştirme sürecinde önemli eylemlerden birisi; okul gelişim yönetim ekibini kurmaktır. Bu ekipte ortak karar alarak iş yapma önem arz etmektedir. Okul gelişim yönetim ekibi; paylaşımc ve iş birliğine 
dayalı yönetim anlayışıyla eğitim-öğretimin niteliğini ve öğrenci başarısını artırmak, okulun fizikî ve insan kaynaklarını geliştirmek, öğrenci merkezli eğitim yapmak, eğitimde planlı ve sürekli gelişim sağlamak amacıyla kurulmaktadır (Gürsül, 2010). Okul yöneticileri okul gelişim modelini “okulu ilerletme" olarak da yorumlamaktadır. Çünkü okul geliştirme; okulun çevresinde değişimlere (bilim, teknoloji, sosyal, küreselleşme, bilgi toplumun beklentileri) paralel olarak kendini sürekli değiştirmesi ve güçlendirmesi gerekmektedir. Bu sayede okulda bir değişim ve ilerleme olmaktadır. Altındağ'a (2008) göre de okul gelişim modeli ile okullarda hedeflenen planlı çalışma sisteminin yerleşeceği ve okul toplumunun bütününün gelişim sürecine katılımı ile de sürekli gelişimin gerçekleşebilir.

Okul geliştirmede yöneticiler planlı ve sistemli çalışamaya da vurgu yapmışlardır. Çünkü İnsan kaynağının geliştirilmesi, dersin/öğretimin iyileştirilmesi ve okulun örgütsel gelişiminin gerçekleşmesi sistem anlayışı çerçevesinde olanaklı olacaktır. Birbirleri ile ilişkili olan ögelerin eşgüdümlü olarak işletilmesi okul geliştirmenin vazgeçilmez temelidir. (Rolff ve diğ., 1998, Akt: Ceylan, 2009). Çalışma sonucunu destekler nitelikte Mintrop ve Maclellan (2002), planlamanın etkili okullarda gerçekleştirilen okul geliştirme sürecinin anahtar unsuru olduğunu belirtmiştir. Jones (1996) okul gelişim planının öğelerinin; program, kaynaklar, personel gelişimi, fiziksel çevre, örgütleme ve yönetim olduğunu belirtmiştir. Okul gelişim planı okulun belirlediği stratejik amaçlarına ve hedeflerine ulaşabilmesi için bir yol haritası niteliği taşır (Gökyer, 2011).

Türkiye'de okul değerlendirmelerinde en önemli ölçütlerden biri okulun akademik başarısıdır. Bundan dolayı okul yöneticileri okulum gelişim modelini akademik başarıyı artıran bir araç olarak yorumlayabilmektedirler. Çünkü okul geliştirme öğrenci başarısını yükseltmeyi amaç olarak benimsemektedir. Balkar'da (2010) yapmış olduğu çalışmada öğrenci başarısını artırmanın okul gelişim planlarının en önemli işlevi olduğu sonucuna ulaşmıştır. Aynı şekilde Tınkılıç (2006) okul gelişim planının amacını, öğrenme ve öğretme süreçlerinin niteliğinin geliştirilmesi olarak belirmektedir. Okul geliştirme çalışmaları, okulu daha etkili ve verimli hale getirebilmek, böylece okulu daha başarılı kılmak ve okul iklimine olumlu yönde katkı sağlamak adına tüm çabaları kapsamaktadır (Yalçın, 2010). Okul yöneticilerine göre okul gelişim modeli eğitim-öğretimi geliştirmede önemli role sahiptir. Etkin 
hazırlanmış okul gelişim planları, öğretim süreçlerinin kalite seviyesinin artırılmasına ve böylece öğrenci başarı seviyesinin artırılmasına odaklanır (Dağ, 2009). Okul gelişim planının amacl, öğrenme ve öğretme süreçlerinin niteliğinin geliştirilmesidir. Böylece daha çok öğrencinin temel disiplin alanlarında gerekli yeterlik düzeylerine ulaşmaları sağlanır (Gökyer, 2011). Okulun örgütsel özelliklerinin yanı sıra eğitim yönetiminde ortaya çıkan yeni eğilimlerde ve toplumsal gelişmelerde okul çevre ilişkilerinin geliştirilmesini kaçınılmaz hale getirmektedir. Özellikle eğitim sistemi/okullar toplumu meydana getiren bireyleri, toplumun taleplerine göre yetiştirmek zorundadır (Yalçın, 2010; Parlar, 2012). Bu durumdan kaynaklı olarak okul yöneticileri okul gelişim modelini okul çevre ilişkisinin geliştirmesi olarak düşünmektedirler. Okul geliştirme sürecinde çalışanların öğrenerek mesleki gelişimini sağlaması gerekmektedir. Okul yöneticileri okul gelişim modelinde tüm paydaşların gelişimi vurgulamıştır. Bu nedenle personel geliştirme okulun etkililiği ve gelişiminin artırılması için bir önkoşuldur. Dolayısıyla, okul planının sürekli personel gelişimini sağlaması önemlidir (Dağ, 2009). Araştırma sonuçlarına göre okul yöneticileri okul gelişim modelini; ortak karar alma, okulu ilerletme, planlı ve sistemli çalışma, akademik gelişme ve okulun çevre ile ilişkisini geliştirme şeklinde yorumlamaktadırlar.

Okul gelişim modellinde önemli öğelerden birisi hedef belirlemedir. Hedefler belirlenirken okulun, çevrenin ve çalışanların özelliklerini, okuldan beklentileri ve okulun kaynaklarını dikkate almak gerekir. Hedefler, bireyleri istenen görevleri yerine getirmek için gerekli çabayı harcama ve daha fazla gayret gösterme konusunda güdülemektedir (Mavisu, 2010). Çalışma sonucunda okul yöneticilerinin okul gelişim modelinde hedef belirlerken; uygulanabilirlik, okul çevresinin durumu, okulun fiziki yapısı/donanımı, sosyoekonomik yapı, öğrenci seviyesi, okulun kaynakları, personel yeterlilikleri, veli profili ve okulun güçlü ve zayıf yönlerini ölçüt aldıkları belirlenmiştir. Planlama açıkça ifade edilmiş ve ulaşılabilir amaçlara dayandırılmalıdır. İyi bir plan kabul edilebilir olmalıdır (Akşit Aşık, 2008). Planlarda öncelikle amaçların açık bir şekilde ifade edilmesi ve içinde bulunulan durumla ilgili incelemelerin yapılması gerekmektedir. Aksi takdirde yapılan planlar hem gerçekçi olmaz hem de örgüt için olumsuz sonuçlara neden olabilir (Özgan ve Kalman, 2015). Okul yöneticilerine göre okul gelişim modelinde hedef belirlenirken okul çevresini dikkate almalıdır. Okul, çevresi, veliler ve yerel yö- 
netimler arasındaki iletişim ve iş birliği geliştirmelidir. Bu durumda okul gelişim süreci daha sağlıklı bir isleyişe kavuşmuş olur (Gülcan, 2009). Okul ve çalışanları iç ve dış dinamiklerden etkilenir. Okullar çalışmalarını yürütürken bu dinamikleri dikkate almalıdırlar. Bu dinamiklerden birisi okulda gerekli olan ekipman, materyal ve donanıma ulaşlabilirliktir. Okulların gelişim sürecinde öncelikle kurumsal kaynakların yeterli olmasına önem verilmelidir. Çünkü yeterli fiziki ve araç-gereç donanıma sahip olmadan okul gelişim süreçlerini gerçekleştirmek zor olabilir. Bu nedenle okul yöneticileri okul gelişim sürecinde hedef belirlerken dikkate ettikleri husus okulun fiziki yapısı ve donanımıdır. Çünkü okul geliştirme ağırlıklı olarak okulun beşerî-sosyal yapısı ve kültürü üzerinde yoğunlaşması ile beraber, yapı ve teknolojik unsurlarında geliştirilmesini ihmal etmemektedir (Yalçın, 2010). Okul gelişim süreci; okulun fiziki ve insan kaynakların geliştirerek eğitimin niteliğini ve öğrenci başarısını artırmayı amaçlamaktadır (İlhan, 2008). Okul geliştirme çabaları, okulu etkileyen ve okul tarafından etkilenen, okul, veli, çevre ile ilişkiler, okulun sahip olduğu araç gereç ve fiziki koşullar, donanım ve insan kaynakları gibi iç ve dış çevresiyle ilgili tüm değişkenleri kapsar (Altındağ, 2008). Bu nedenle okul gelişim modelinde hedef belirlenirken bu değişkenleri dikkate almak okul gelişim modelinin uygulanabilirliğini artıracaktır.

Araştırmada; okulun gelişmesi için eğitim-öğretime ve personele yönelik çalışmalara önem verilmesi gerektiği sonucuna ulaşılmıştır. Eğitim-öğretime yönelik yapılması gerekenlerde; öğrencilerin gelişimini sağlama, fiziki şartları/ortamı iyileştirme, okul aile iş birliğini sağlama ve eğitim sisteminin revize edilmesi konularına daha fazla önem verilmektedir. Çünkü okul geliştirme girişimleri sonuç olarak sınıfın ve öğretimin geliştirilmesi için yapılan girişimlerdir (Ceylan, 2009). Okul gelişim sürecinde aile ile iş birliği önemlidir. Çünkü okul ile iş birliği içinde olan ailelerin çocuklarına eğitim desteği sağladığı ve bu nedenle öğrencilerde olumlu davranış kazandırma ve bu durumun sürekliliğini sağlamada verimliliği arttırmaktadır (Yalçın, 2010). Bu nedenle okul yöneticileri okul gelişim sürecinde aile ile iş birliğinin yapılması gerektiğini belirtmişlerdir. Okul gelişiminde çalışanların da kendilerini geliştirmesi gerekmektedir. Bu duruma bağlı olarak okul yöneticileri gelişim sürecinde öğretmenlerin mesleki gelişiminin okul gelişim sürecinde bir gereklilik olarak belirtmişlerdir. Okul gelişiminde organizasyon, eğitim ve personel geliştirme sentezi vardır (Parlar, 2012). Personel geliştirme kişisel gelişim, grup gelişimi ve okul gelişimini kapsar. Bu durum; öğretmenlerin kişisel ve 
mesleki gelişim yaşamlarını geliştirir, okul amaçlarının uygulanması için zemin hazırlar ve değişimin başlangıcını kolaylaştırır (Dağ, 2009). Çünkü öğretmen geliştirme okul geliştirmenin bütünleyici bir parçasıdır (Balcı, 2014).

Araştırma sonucunda okul gelişim modeli planı hazırlarken planlamanın amacına ve uygulanabilirliğine ve çalışma ekibinin oluşturulmasına dikkat edilmesi gerektiği tespit edilmiştir. Planlama süreci; okul gelişim planın temel süreçleri gözden geçirme, tasarım, uygulama ve değerlendirmedir (Tınkılıç, 2006). Etkili bir okul planı; okulun performans düzeyini etkiler, yönetim, öğrenme ve öğretme süreçlerini destekleyecek olumlu faktörlerin etkisini artırmayı amaçlar (Gürsül, 2010). Balkar (2010) yatığ1 çalışmada öğretmenler okul gelişim planının başlıca işlevini okulu geliştirme olduğunu belirtmişlerdir. Çalışmada okul gelişim modelinin uygulanabilirliğini artırmak için çevrenin desteğini almak gerektiği sonucuna ulaşılmıştır. Okul gelişim yönetim ekibi okul toplumunu temsil edeceği için okul toplumunu oluşturan bütün birimlerin temsil edebileceği üyelerden oluşur (İlhan, 2008). Bu üyeler (Okul Gelişim Yönetim Ekibi), okul dışındaki kurum ve kuruluşlar ile okul yönetimi arasındaki koordinasyonu sağlamak için daha etkili çalışmalıdır (Dağll, 2009). Okul gelişim yönetim ekibi hem velileri hem de okulu etkileyen ve ilişki kurduğu çevredeki özel ve resmî kurumları (muhtarlık, belediye, sivil toplum örgütlerinden-okul çalışmalarının etkililiğini artıracağı düşünülen sendikalar, dernek, vakıf, sanayi ve ticaret odaları) okul gelişim raporu hakkında yeterince bilgilendirmesi gerekir (Gökyer, 2011).

Araştırmada paydaşların (yönetici, öğretmen, veli vb.) okul gelişim planındaki rolü/katkısı belirlenmeye çalışılmıştır. Okul yöneticileri okul gelişim sürecinde yöneticinin rolünü liderlik olarak tanımlamaktadırlar. Okul yöneticisi, okulu kuruluş amaçlarına uygun olarak yaşatmalıdır. Tüm bu hedeflerin gerçekleşmesi için okul yöneticisinin birçok özelliğe sahip olması gerekmektedir (Yalçın, 2010). Okul yöneticisinin rollerinin, spesifik yeniliklerin uygulanmasını etkilemekten bir örgüt olarak okulda değişmeye liderlik etmeye doğru değiştiği görülmektedir (Balcı, 2014). Bu anlamada liderlik, bir örgütün amaçlarını gerçekleştirme ya da bu amaçları değiştirmek için yeni bir yapı ve prosedür başlatma olarak tanımlanabilir (Erdoğan, 2012). Okul yöneticisi; öğrendiklerini uygulayan, öğrenmede öncülük eden, yenileşme ihtiyaçlarını görebilen, çağın teknolojik yeniliklerini tüm okula sunmaya çalışan ve okulu bütün olarak kabul eden ve değişim girişimlerini gerçekleştirmeye çalışan lider olmalıdır (Beycioğlu ve Aslan, 2010). Okulun gelişiminde en büyük rolün 
okul yöneticilerine düşmektedir. Dolaysıyla yöneticilerin bu konudaki yeterliliklerinin geliştirilmesinin üzerinde önemle durulması gereken bir konu olduğu unutulmamalıdır (Gürsül, 2010). Araştırmada okulun gelişim sürecinde öğretmenlerin rolleri daha çok planı uygulama aşamasında ortaya çıtığı saptanmıştır. Okulun gelişiminde yöneticiler kadar öğretmenlere de önemli görevler düştüğü unutulmamalıdır. Bu bağlamda, öğretmenlere de bu konuda sorumluluklar vermek, yöneticinin çeşitli yetkilerini zaman zaman öğretmenlere vermesi ve öğretmenleri bu konuda motive etmek önemli bir durumdur (Gürsül, 2010). Değişimle gelebilecek herhangi bir yeniliği okul da ve sınıf ortamında uygulayabilecek kişi öğretmendir. Eğer öğretmen yeniliğe inanmamışsa ya da benimsememişse, bu girişim baştan kaybedilebilir (Beycioğlu ve Aslan, 2010). Okul gelişim sürecinde velilerin rolünün olduğu sonucuna ulaşılmıştır. Velilerin okulun fiziki kaynaklarını ve okul çevre ilişkisini geliştirmede önemli rolleri vardır. Ayrıca okulda yapılan faaliyetlerin en önemli destekçisinin veli olduğu unutulmamalıdır.

Araştırmada okul gelişimini engelleyen unsurlarda kaynak yetersizliğinin önemli bir engel olduğu tespit edilmiştir. Ceylan'da (2009) yaptığı araştırmada; okul yönetim hizmetlerinde maddi kaynak sorununun yaşandığı bulgusuna ulaşmıştır. Tınkılıç (2006) yapmış olduğu çalışmada; okulların fiziki durumlarının çalışmalara uygun olmadığı sonucuna ulaşmıştır. Okul geliştirmede fiziki şartları iyileştirilmek asgari şartlardan bir tanesidir. Para, zaman, okulun mekânları gibi fiziksel kaynaklar ile insan kaynaklarının yetersizliği planlamada genellikle karşılaşılan bir sorundur (Gülcan, 2009). Okul gelişiminde velilerin ilgisizliği de en önemli engellerden biridir. Gökyer'de (2011) yaptığı çalışmada; okul ile aile arasında kurulan iletişimin ve okulun çevresindeki kuruluşlarla olan ilişkisinin yetersiz olduğu sonucuna ulaşmıştır. Okul gelişiminde öğretmenlerin değişime ve yeniliğe kapalı olması okuldaki gelişimi engellediği sonucuna ulaşılmıştır. Hâlbuki gelişimin olabilmesi için öğretmenlerin kendilerini değişime hazırlamaları ya da değişim olgusuyla barışık olmaları gerekmektedir (Beycioğlu ve Aslan, 2010). Öğretmenin yenilik konusunda kendini yeterli görmesi, sonra da yeniliğin değerine ilişkin algısı yeniliğin uygulanma ve tutunmasında önemli rol oynamaktadır (Balc1, 2014). Okul gelişim sürecinde okul gelişimini engelleyen ve destekleyen unsurlara dikkate alınarak hazırlanmalıdır. Çünkü etkili bir okul planı; olumlu faktörlerin etkisini artırmayı amaçlarken olumsuz faktörlerin etkisini en aza indirgemeyi sağlayacak stratejileri içermelidir (Gökyer, 2011). 
Araştırmada okul gelişiminin engellerine yönelik çözüm önerilerinin; okullara yeterli düzeyde kaynak sağlama, velilerin bilinçlendirilmesi, öğretmenlere gelişime yönelik hizmetiçi eğitimlerin verilmesi ve uygulanabilir hedefler belirleme olduğu sonucuna ulaşılmıştır. Okul gelişim yönetim ekibinin başarılı olması için Okul-Aile Birliği bütçesinden yeterli bir ödenek ayrılması gerekmektedir (Dağlı, 2009). Okulun paydaşlarından velilerin planlı okul gelişim modeli konusunda bilgilendirilmeleri sağlanmalıdır. Buna yönelik toplantılar düzenlenerek sürece velilerin de katılımı gerçekleştirilmelidir (Altındağ, 2008). Okullarda okul gelişim yönetim ekibine çalışmaları hakkında bilgilendirici toplantı ve panellerin yapılması gerekmektedir (Dağlı, 2009).

Araştırma sonucunda; okul yöneticileri okul gelişiminin uygulama sürecinde; fiziki şartların iyi olmasın, veli profilini, öğretmen kadrosunu ve öğrenci profilini önemli firsat olarak görmektedir. Altun ve Bebek (2016) tarafından yürütülen bir araştırma sonucunda, okulun gelişiminin, okulun fiziksel imkânlarının gelişmişliği, öğretmenlerin meslek sevgisi ve öğrencilerin akademik başarısı ile ilgili olduğu ortaya çıkmıştır. Benzer şekilde yapılan çeşitli araştırmalarda da (Poyraz ve Dere, 2003; Karaküçük, 2008) okulların fiziksel açıdan yeterli olmasının öğrencilerin ve dolayısıyla okulun başarısı için önemli bir faktör olduğu belirtilmiştir. Okulun alt yapı imkânların yeterliliği, öğretmenlerin gelişimlerinin desteklenmesi ve öğrencilerin araştırmaya sevk edilmesi okulun gelişimi için önemlidir (Turan, 2002; Balkar ve Özgan, 2010; Altun ve Cengiz, 2012). Araştırmada okul gelişim sürecinin değerlendirilmesinde; hedeflerin gerçekleşme düzeyi ve akademik başarının ölçüt alınması gerektiği sonucuna ulaşılmıştır. Okul gelişim sürecinde sürekli izleme ve değerlendirme yapılarak hedeflerin gerçekleştirilme düzeyi tespit edilmelidir. İzleme, planlama uygulamasının sistematik olarak takip edilmesi ve raporlanmasıdır. Değerlendirme ise, uygulama sonuçlarının amaç ve hedeflere k1yasla ölçülmesi ve söz konusu amaç ve hedeflerin tutarlllık ve uygunluğunun analizidir (Altındağ, 2008). Okul gelişim süreci birbirini takip eden plânlama, uygulama, değerlendirme, düzeltme ve tekrar plânlamaya dönme basamaklarından oluşmaktadır. Bu özelliği ile okul gelişim süreci, sürekli olarak kendi kendini değerlendiren, değerlendirme sonuçlarına göre kendi kendini düzenleyerek geliştiren dairesel bir süreçtir (Tınkılıç, 2006). Bu süreçler ise; okul idaresi, öğretmen, veli, öğrenci ve okul dışından uzman bir ekiple sürekli takip edilmelidir. Çünkü bu paydaşların bir kısmı okul gelişim yönetim ekibinde yer almakta, bir kısmı ise uygulama süreçlerinde görev alan kişilerdir. 
Ayrıca okul dışından uzmanların bulunması değerlendirme sürecine objektiflik sağlayacaktır.

Araştırmadan elde edilen bulgular doğrultusunda hem araştırmacılar hem de uygulayıclar için birtakım önerilerde bulunmak mümkündür. Okul gelişim modelinde eğitim-öğretim ve personelin gelişimine yönelik belirlenen hedeflerin gerçekleştirebilir olması önem arz etmektedir. Bundan dolayı okul gelişim modelinde hedefler belirlenirken varolan durum dikkate alınarak hedefler belirlenmelidir. Okul gelişim modeli oluştururken tüm paydaşlar sürece katmak önem arz etmektedir. Bundan dolayı okul gelişim planının sahiplenmesini ve uygulanabilirliğini artırmak için paydaşların katılımına önem verilmelidir. Bu durum, olumlu ve güven odaklı bir okul kültürünün oluşmasını sağlayacaktır. Okul gelişimi için okulun belirli kaynaklara fiziksel imkanlara sahip olması gerekmektedir. Bundan dolayı okul gelişiminde en önemli engellerden biri olan kaynak eksikliğinin giderilmesine yönelik çalışmalar yapılmalı veya okul gelişiminde kaynak yeterliliğine ulaşmaya yönelik hedefler belirlenmelidir. Okul paydaşlarının en önemli öğesi olan velinin okul gelişimine doğrudan ve dolaylı desteğini sağlayacak çalışmalara yer verilmelidir. Araştırmada Okul Gelişim Modeli (OGM) ile ilgili olarak ilkokullarda görev yapan yöneticilerin görüşleri alınmıştır. Bu nedenle farklı kademelerde konu ile ilgili araştırmalar yapılarak sonuçlar arasındaki benzerlik ve farklılıklar ortaya çıkarılabilir. Ayrıca, farklı şehirlerde, farklı örneklemlerde araştırmalar yapılabilir. Dahası, nicel ve karma yöntemde araştırmalar yapılarak nitel ve nicel sonuçlar bütüncül bir şekilde sunulabilir. Okulda yöneticilerin yanı sıra öğretmenlerin konu hakkındaki düşüncelerini belirlemeye yönelik olarak öğretmen örneklemi ile araştırmalar yapılabilir. 


\title{
EXTENDED ABSTRACT
}

\section{School Administrators' Perceptions of School Development Model}

\author{
$*$ \\ Fatih Bozbayındır - Sedat Alev \\ Gaziantep University, Ministry of National Education
}

Adaptation of schools to transformations and innovations experienced can be actualized by participating in activities aimed at ensuring schools' development in a planned way. School development determines the direction of the school by evaluating how a school can be developed and which resources can be used by whom and how, forming a framework for implementations in the school (Şahin, 2013). To develop a school, administrators should be individuals who ensure the development of all the personnel serving in the school and the students, who support employees and ease their jobs while providing cooperation and coordination between parents and stakeholders of the school. To ensure schools' development, material and human resources should be efficiently used and coordinated. At this point, the most important duty falls to school administrators.

Within this framework, in this study, it was aimed to determine school administrators' perceptions of the school development model (SDM). In line with this main aim, answers to the following questions were sought:

1. What are your thoughts about the SDM?

2. In the school development model, what should the benchmarks be while setting goals for schools?

3. According to you, what should be done to develop schools?

- What should be done about education?

- What should be done about personnel?

4. What should be considered while preparing the SDM plan?

- What should be done to improve the practicality of school development plans in a school?

- What is the role/contribution of stakeholders (administrators, teachers, parents, etc.) in the school development plan? 
5. In the SDM implementation process, what do you think are the barriers that your school faces and what should be done to eliminate those barriers?

6. In the SDM implementation process, what do you think the opportunities your school has ahead are and how does your school make use of these opportunities?

7. In the evaluation of the SDM process, which criteria should be taken into account and by whom should the evaluation be conducted?

This study was conducted via the case study method, which is one of the qualitative research designs. The study group of the research consists of administrators who served in primary schools. The administrators who make up the study group were chosen via the purposeful sampling method. The study group consists of 21 school administrators who serve in primary schools. 9 of the administrators are principals while 12 of them are assistant principals. The data were collected by a semi-structured interview form. The interviews were conducted in the schools where the administrators served within the principals' knowledge. In the analysis of the data obtained from the interviews conducted, descriptive analysis and content analysis were employed. The data were analyzed by using MAXQDA 2018 qualitative data analysis software.

In the study, the administrators were first asked the question, "What are your thoughts about the school development model? The school administrators defined the school development model as "shared decision making, improving the school, planned and systematic actions and improving academic achievement". In terms of setting goals in the school development model, it was discovered that the school administrators considered the benchmarks, "practicality, state of the school's environment, school's physical condition/equipment, socioeconomic structure and level of students". According to school administrators, activities oriented toward education and personnel should be accommodated to develop the school. Activities oriented toward education cover ensuring students' development, improving physical conditions/environment, providing cooperation between school and parents, revising the education system and forming a cooperation and confidence environment. To develop the school, activities oriented 
towards personnel cover developing teachers' competences, rewarding/motivating successful teachers, encouraging participation in in-service training and providing education aimed at implementations.

According to school administrators, the goal of the plan, its practicality and the planning team should be taken into account while preparing the school development model plan. According to school administrators, aspects such as achieving the goal, improving achievement, developing the school, guiding and ensuring orders should be taken into account while setting the goals of the plan. For the practicality of the plan, it is important to set achievable goals, ensure the support of every stakeholder, consider the financial status of the school and motivate the teachers. According to school administrators, the school planning team should include the school administration, the president of parent-teacher associations and non-governmental organizations (NGO). It was found out that principals should assume the role of leadership and ensuring coordination in this team. It was also discovered that the role of teachers should be implementing the plan and generating ideas. In the school planning team, it was determined that parents should assume the roles of supporting the activities and meeting the financial needs of the school.

In the study, it was discovered that the elements that hindered the school development process included insufficient resources, insufficient support from parents, a crowded number of students, teachers' refusal of innovation and transformation and inadequate physical conditions of the school. The suggestions of school administrators to eliminate these obstacles include providing sufficient resources to schools, raising the awareness of parents, providing in-service training to teachers and improving the physical conditions of schools. In the school development process, school administrators regarded good physical conditions, parent profile, teaching staff, student profile and cooperation between stakeholders as opportunities. To make use of these opportunities, school administrators stated that support of parents and physical areas should be used effectively. In the evaluation of the school development process, school administrators expressed that level of goal achievement and academic achievement should be taken into account. It was discovered that the evaluation team for the school development should be formed from teachers, parents, school administration, students and a team of experts from outside of the school. 
In the conclusion of the study, the administrators stated that school development is implemented to develop the school in a planned and systematic way and practicality should be taken into account while setting goals. To achieve the goals, planning is important and necessary while every stakeholder of schools should play roles in the planning process. It was emphasized that the physical conditions of schools should be improved and adequate resources should be provided in addition to the use of the level of goal achievement and academic achievement as benchmarks in the evaluation process. To conduct educational effectively, it is regarded as vitally important to ensure that every stakeholder actively participates in the process and to form a positive and confidence-focused school culture. To ensure schools' development, sufficient resources should be provided while taking environmental conditions into account and rending physical conditions accommodating. It is believed that conducting studies on developing teachers' competences will enable them to support schools' development by encouraging them to play more active parts in innovation and transformation.

\section{Kaynakça / References}

Ada, Ş., Akan, D., Ayık, A., Yıldırım, İ. ve Yalçın, S. (2013). Öğretmenlerin motivasyon etkenleri. Atatürk Üniversitesi Sosyal Bilimler Enstitüsü Dergisi, 17(3), 151-166.

Altındağ, S. (2008). İlköğretim okul müdürlerinin planlı okul gelişimi uygulama düzeylerinin değerlendirilmesi:İstanbul İli örneği. Yayımlanmamış yüksek lisans tezi. Kırıkkale Üniversitesi, Kırıkkale.

Altun, T. ve Bebek, G. (2016). Öğretim elemanlarının okul geliştirme ve etkili okul paradigmalarının temel bileşenleri hakkındaki görüşlerinin incelenmesi. Alan Eğitimi Araştırmaları Dergisi, 2(2), 96-107.

Altun, T. ve Cengiz, E. (2012). Upper primary school teachers' views about professional development opportunities. International Online Journal of Educational Sciences, 4(3), 672-690.

Akşit Aşık, N. (2008). Planlama (Ed. Ayden, C. ve Örgev, M. (Yönetim ve Organizasyon). İstanbul: Lisans Yayıncilik.

Anfara Jr, V. A., Patterson, F., Buehler, A., ve Gearity, B. (2006). School improvement planning in East Tennessee middle schools: A content analysis and perceptions study. NASSP Bulletin, 90(4), 277-300.

Balc1, A. (2011). Etkili okul ve okul geliştirme: Kuram uygulama ve araştırma (5. basım). Ankara: PegemA Yayıncilı. 
Balkar, B. (2010). Okul gelişim planı ve etkililiğinin sağlanması hakkında öğretmen görüşleri. Atatürk Üniversitesi Sosyal Bilimler Enstitüsü Dergisi, 14(2), 165-181.

Balkar, B. ve Özgan, H. (2010). Küreselleşmenin ilköğretim kademesindeki eğitim sürecine etkilerine ilişkin öğretmen görüşleri. Mehmet Akif Ersoy Eğitim Fakültesi Dergisi, 10(19), 1-22.

Beycioğlu, K. ve Aslan, M. (2010). Okul gelişiminde temel dinamik olarak değişim ve yenileşme: Okul yöneticileri ve öğretmenlerin rolleri. Yüzüncü $Y_{\imath} l$ Üniversitesi Ĕ̆itim Fakültesi Dergisi, 7(1), 153-173.

Bozbayındır, F. ve Alev, S. (2018). Öğretmenlerin öz yeterlilik, proaktif kişilik ve değişime açıklık algıları arasındaki ilişkinin incelenmesi. İnönü Üniversitesi Ĕ̆itim Fakültesi Dergisi, 19(2), 293-311. DOI:10.17679/inuefd.346666

Ceylan, M. (2009). Okul Yöneticilerinin okul geliştirme danışmanlık hizmetine ilişkin görüşleri:Eskişehir İli örneği. Yayımlanmamış doktora tezi. Anadolu Üniversitesi, Eskişehir.

Christensen, L.B., Johnson, R.B. ve Turner, L.A. (2015). Araştırma yöntemleri: Desen ve analiz. (A. Aypay. Çev. Ed.). Ankara: Anı Yayıncılık.

Clarke, S. P. (2000). The principal at the center of the reform. International Journal of Leadership in Education, 3, 57-73.

Creswell, J. V. (2016). Nitel araştırma yöntemleri: Beş yaklaşıma göre nitel araştırma ve araştırma deseni.(M. Bütün ve S. B. Demir. Çev. Ed.).Ankara:Siyasal Kitabevi.

Creswell, J. W., Hanson, W. E., Clark Plano, V. L., ve Morales, A. (2007). Qualitative research designs: Selection and implementation. The Counseling Psychologist, 35(2), 236-264.

Dağ, Ş. (2009).istanbul ili resmi ilköğretim okullarının okul gelişim ihtiyaçlarının belirlenmesi.Yayımlanmamış yüksek lisans tezi.Yıldız Teknik Üniversitesi,İstanbul.

Dağlı, E. (2009). İlköğretim okullarında okul gelişim yönetim ekibi çalışmalarının yönetici ve öğretmen görüslerine göre değerlendirilmesi. Yayımlanmamış yüksek lisans tezi. Gazi Üniversitesi, Ankara.

Erdoğan, İ. (2012). Eğitimde değişim yönetimi. Ankara: PegemA Yayıncılık.

Gökyer, N. (2011). İlköğretim okullarındaki okul gelişim yönetim ekibi üyelerinin görevlerine ilişkin algıları. Selçuk Üniversitesi Sosyal Bilimler Enstitüsü Dergisi, 25, 345-358.

Gülcan, F. (2009). MEB'e bağh okullarda yürütülen okul geliştirme çalışmalarının uygulanma düzeyi ve karşılaşılan problemler Nevşehir İli örneği. Yayımlanmamış yüksek lisans tezi. Sakarya Üniversitesi, Sakarya. 
Gürsül, E. (2010). İlköğretim okulu yöneticilerinin okul gelişimine etki düzeyleri. Yayımlanmamış yüksek lisans tezi. Yeditepe Üniversitesi, İstanbul.

Harris, A. (2002). School improvement: What's in it for schools? London, New York: Routledge.

Heck, R.H. ve Hallinger, P.(2010).Testing a longitudinal model of distributed leadership effects on school improvement.The Leadership Quarterly,21,867-885.

Hopkins, D. (2004). School improvement for real. Canada: Routledge Falmer.

İhan, İ. H. (2008). Okul gelişim yönetim ekibi modelinin ticaret meslek liselerinde uygulanışının incelenmesi.Yayımlanmamış yüksek lisans tezi.Yeditepe Üniversitesi, İstanbul.

Jones, G.R. (1996). School development planning in Jersey primary schools: A continency analysis. School Organisation, 16(3), 281-295.

Karaküçük, S. A. (2008). Okul öncesi eğitim kurumlarında fiziksel/mekânsal koşullarına incelenmesi: Sivas ili örneği. Cumhuriyet Üniversitesi Sosyal Bilimler Dergisi, 32(2), 307-320.

Mavisu, H. (2010). Bireysel kariyer planlamanın aşamalarından biri olarak hedef belirleme ve kariyer başarısı ilişkisi. Yayımlanmamış doktora tezi. Dokuz Eylül Üniversitesi, İzmir.

Miles, M. B. ve Huberman, A. M. (2015). Nitel veri analizi. (S.A. Altun ve A. Ersoy Çev. Ed.). Ankara: Pegem Akademi.

Mintrop, H., ve MacLellan, A. M. (2002). School improvement plans in elementary and middle schools on probation. The Elementary School Journal, 102(4), 275-300.

Opdenakker, M. C., ve Damme, J.V. (2007). Do school context, student composition and school leadership affect school practice and outcomes in secondary education? British Educational Research Journal, 33(2), 179-206.

Özgan, H. ve Kalman, M. (2015). Yönetim süreçleri. (Ed: Çiçek Sağlam, A. Türk eğitim sistemi ve okul yönetimi). Ankara: Maya Akademi.

Parlar, H. (2012). Okul geliştirme literatürünün modeller ve yeni yaklaşımlar açısından incelenmesi: Kuramsal analitik bir yaklaşım. Yayımlanmamış doktora tezi. Marmara Üniversitesi, İstanbul.

Patton, M. Q. (2014). Nitel araştırma ve değerlendirme yöntemleri. (M. Bütün ve S.B. Demir Çev. Ed.). Ankara: Pegem Akademi.

Penlington, C., Kington, A., ve Day, C. (2008). Leadership in improving schools: a qualitative perspective. School Leadership and Management, 28(1), 65-82.

Poyraz, H. ve Dere, H. (2003). Okul öncesi eğitimin ilke ve yöntemleri.Ankara:Anı Yayınclik. 
Reynolds, D., Harris, A., Clarke, P., Harris, B., ve James, S. (2006). Challenging the challenged: Developing an improvement programme for schools facing exceptionally challenging circumstances. School Effectiveness and School Improvement, 17(4), 425-439.

Smylie, M. A., Conley, S., ve Marks, H. M. (2002). Exploring new approaches to teacher leadership for school improvement. Yearbook of the National Society for the Study of Education, 101(1), 162-188.

Stemler, S. (2001). An overview of content analysis. Practical Assessment, Research E Evaluation, 7(17), 137-146.

Şahin, İ.(2006).İlköğretim müfredat laboratuvar okullarmmn okul geliştirme süreci açısından incelenmesi.Yayımlanmamış doktora tezi.Dokuz Eylül Üniversitesi,İzmir.

Şahin, İ. (2013).Illköğretim okul müdürlerinin okul geliştirme stratejileri ve uygulamalarına ilişkin görüşleri.Kuram ve Uygulamada Eğitim Bilimleri, 13(1),229-250.

Teddlie, C., ve Yu, F. (2007). Mixed methods sampling: A typology with examples. Journal of Mixed Methods Research, 1(1), 77-100.

Tinkılıç, C. (2006). Ilköğretim okullarında yürütülen okul geliştirme çalışmalarının karşılaştırmah analizi Ankara ve Stuttgart şehirleri örneği. Yayımlanmamış yüksek lisans tezi. Gazi Üniversitesi, Ankara.

Turan, S. (2002). Teknolojinin okul yönetiminde etkin kullanımında eğitim yöneticisinin rolü. Kuram ve Uygulamada Ĕ̆itim Yönetimi, 30, 271-281.

Türnüklü, A. (2000). Eğitimbilim araştırmalarında etkin olarak kullanılabilecek nitel bir araştırma tekniği: Görüşme. Kuram ve Uygulamada Eğitim Yönetimi Dergisi, 6(4), 543-559.

Yalçın, F. (2010). Ilköğretim okulu yöneticilerinin yürütmekte oldukları okul geliştirme çalı̧malarımın incelenmesi Kastamonu ili örneği. Yayımlanmamış yüksek lisans tezi. Gazi Üniversitesi, Ankara.

Yıldırım, A. ve Şimşek, H. (2013). Sosyal bilimlerde nitel araştırma yöntemleri (9. baskı). Ankara: Seçkin Yayıncllı.

\section{Kaynakça Bilgisi / Citation Information}

Bozbayındır, F. ve Alev, S. (2020). Okul yöneticilerinin okul gelişim modeli ile ilgili görüşleri. OPUS-Uluslararası Toplum Araştırmaları Dergisi, 15(24), 2640-2673. DOI: 10.26466/opus.667359 